\title{
Spatial and temporal variability of tidepool hyperbenthos on a rocky shore in Nova Scotia, Canada
}

\author{
Anna Metaxas, Robert E. Scheibling \\ Department of Biology, Dalhousie University, Halifax, Nova Scotia, Canada B3H 4J1
}

\begin{abstract}
We examined the distribution and abundance of the hyperbenthos in tidepools on a rocky shore, near Halifax, Nova Scotia, Canada, at approximately monthly intervals between March and November 1991, and between April and June 1992. We sampled 4 pools at each of 3 intertidal heights: mid and high intertidal and splash zones. Additional samples were taken at the sea surface for comparison. Calanoid and harpacticoid copepods, cladocerans, foraminiferans, nematodes and rotifers were the most abundant groups within our samples. Significant differences in the abundance of these groups among zones were detected on only 5 out of 12 sampling dates. Total hyperbenthos, as well as calanoid and harpacticoid copepods, nematodes and rotifers, generally were more abundant in the high and/or the splash pools. The abundance of total hyperbenthos varied significantly among pools within zones from May to October 1991 and in June 1992. Significant differences in abundance among pools within zones were also detected for harpacticoid copepods and nematodes on 3 sampling dates, for calanoid copepods and rotifers on 5 sampling dates, and for cladocerans and foraminiferans on 2 sampling dates. In most cases, the significant variability in abundance among pools arose within the high intertidal or the splash zones. Over the entire sampling period, the diversity of faunal groups was lower in the splash pools, possibly as a result of harsh conditions in these pools. The few groups that survived in these high pools, such as rotifers and the calanoid copepod Eurytemora affinis, reached densities of up to $10^{6}$ ind $\mathrm{m}^{-3}$. Dominant populations may be established in particular pools by founder effects and persist due to low flushing rates. Thus, variability among pools in the high intertidal and splash zones may exceed that observed among pools in lower intertidal zones.
\end{abstract}

KEY WORDS: Diversity - Hyperbenthos · Rocky intertidal zone - Spatial and temporal variability Tidepools $\cdot$ Zonation

\section{INTRODUCTION}

Among the motile benthos of the emergent substrata of intertidal rocky shores are meio- and macrofauna, such as harpacticoid copepods, amphipods and polychaetes, which swim during submergence but attach to the substratum or to macroalgae during emergence (Hawkins \& Hartnoll 1983, Hicks \& Coull 1983, Dean \& Connell 1987a, b, Johnson \& Scheibling 1987, Gibbons 1988, 1989, Janke 1990). In tidepools, these animals are continuously submerged and can actively swim and feed during their entire cycle. Tidepools also are microhabitats for zooplankton such as calanoid copepods or cladocerans, which feed only in the water column, spend most of their time swimming and are not found on the emergent rocks (Fraser 1936, Naylor \& Slinn 1958, Ganning 1971, Goss-Custard et al. 1979, Preston \& Moore 1988, Metaxas \& Scheibling 1993). Some groups, such as amphipods, may be present in constant abundance in pools throughout the year (Femino \& Mathieson 1980, but see Ganning 1971), while others, such as harpacticoid copepods, show large seasonal variations in abundance (Goss-Custard et al. 1979). The abundance of motile fauna also may vary with increasing intertidal height of the tidepools (Metaxas \& Scheibling 1993). For example, harpacticoid copepods are generally more abundant in tidepools located high on the shore (Fraser 1936, Dethier 1980), whereas calanoid copepods and amphipods are more abundant in tidepools located lower on the shore 
(Fraser 1936, Ganning 1971, Femino \& Mathieson 1980 but see Naylor \& Slinn 1958). However, most studies have not measured abundance quantitatively or have shown high variability in abundance among pools within the same intertidal zone, which can mask height effects (e.g. see Naylor \& Slinn 1958, Metaxas \& Scheibling 1993).

In this study, we examined spatial and temporal patterns of the horizontal and vertical distribution and abundance of the motile fauna or 'hyperbenthos' (sensu Beyer 1958, as cited in Sibert 1981) of tidepools in each of 3 intertidal zones (mid, high, splash) on a rocky shore in Nova Scotia, Canada. We compared the variability in abundance, over a 15 mo period, among tidepools within the same zone to the variability among zones and at the sea surface. These patterns of variation are discussed in relation to differences in tidal input and physical conditions among zones and provide a basis for further studies of the mechanisms regulating the structure and dynamics of this poorly known faunal assemblage of tidepools.

\section{MATERIALS AND METHODS}

Four tidepools, at each of 3 zones (mid, high and splash, determined by the isolation period of the tidepools; see below) along the intertidal gradient, were sampled at approximately monthly intervals between March and November 1991, and between April and June 1992, at Cranberry Cove, Nova Scotia $\left(44^{\circ} 28^{\prime} \mathrm{N}, 63^{\circ} 56^{\prime} \mathrm{W}\right)$. The pools were irregularly shaped with the maximum dimension ranging from 2 to $14 \mathrm{~m}$ and maximum depth ranging from 0.21 to $0.75 \mathrm{~m}$. Surface area ranged from 0.68 to $24.23 \mathrm{~m}^{2}$ and water volume ranged from 0.2 to $7.3 \mathrm{~m}^{3}$. The period of isolation of each tidepool was measured by recording the period between tidal recession and subsequent tidal input (including spray) on 17 occasions (in June 1990 and at approximately monthly intervals between March 1991 and November 1992). The isolation period ranged from 3 to $8 \mathrm{~h}$ in the pools in the mid zone and from 10 to $12 \mathrm{~h}$ in the pools of the high zone (Table 1). The height above chart datum of each tidepool was measured using a transit level in July 1991 and 1992 and ranged from 1.1 to $2.3 \mathrm{~m}$ for the pools in the mid zone, from 2.5 to $3 \mathrm{~m}$ for pools in the high zone, and from 2.8 to $4.5 \mathrm{~m}$ for pools in the splash zone (Table 1). Flushing rate was determined as the percent decrease in the concentration of a fluorescent red dye (Rhodamine B, Sigma ${ }^{\circledR}$ Chemicals), added to the tidepools in a solution of known concentration over the period between low and high tide. Flushing rate was measured on 2 occasions: 9 July 1992, when wave height was 2 to $3 \mathrm{~m}$ and it was raining lightly, and
Table 1 Physical characteristics of 4 tidepools at each of 3 intertidal zones at Cranberry Cove, Nova Scotia. Flushing rate: \% volume of water that is turned over in the period between low and high tide measured in July 1992 and August 1993. The isolation period of the splash pools was not measured but in summer was $>1$ mo. Data are mean $\pm \mathrm{SD}$ for 4 replicate pools at each intertidal zone

\begin{tabular}{|ccccc|}
\hline $\begin{array}{c}\text { Intertidal } \\
\text { zone }\end{array}$ & $\begin{array}{c}\text { Isolation } \\
\text { period } \\
\text { (h) }\end{array}$ & $\begin{array}{c}\text { Height above } \\
\text { chart datum } \\
(\mathrm{m})\end{array}$ & \multicolumn{2}{c|}{ Flushing rate (\%) } \\
Mid & $5.8 \pm 2.2$ & $1.5 \pm 0.5$ & $78 \pm 30$ & $86 \pm 25$ \\
High & $11.2 \pm 1.0$ & $2.8 \pm 0.2$ & $36 \pm 23$ & $32 \pm 46$ \\
Splash & - & $3.7 \pm 0.7$ & $31 \pm 22$ & $6 \pm 5$ \\
\hline
\end{tabular}

30 August 1993, when wave height was ca $1 \mathrm{~m}$ and it was not raining. Flushing rate was highly variable among pools in each zone but decreased on average with increasing tidal height (Table 1). Mean flushing rate was similar for both measurements in the mid and high zones, but was higher on the first measurement in the splash zone due to increased dilution by waves and rain (Table 1).

In each tidepool, 2 samples of hyperbenthic fauna were collected by hand-pumping $5 \mathrm{l}$ of seawater from 10 to $20 \mathrm{~cm}$ above the bottom of the tidepool (sediment/water interface, approximately the mid depth of the pools) through a $60 \mu \mathrm{m}$ net. The net was then rinsed into a container and the sample fixed with $4 \%$ buffered formaldehyde. Two other samples were collected similarly at the sea surface at each of 2 locations along the shore separated by approximately $250 \mathrm{~m}$. The fauna were identified to the lowest taxonomic level possible (see Appendix 1) according to Smith (1964), Brinkhurst et al. (1976), Barnes (1980) and Gardner \& Szabo (1982) and enumerated using a Leitz Labovert inverted microscope.

The fauna were assigned to the following taxonomic groups: amphipods, barnacle nauplii, calanoid copepods, cladocerans, cyclopoid copepods, foraminiferans, harpacticoid copepods, isopods, mites, nematodes, ostracods, polychaetes and rotifers. Taxonomic groups with abundances $>25 \%$ of the total abundance of the hyperbenthic fauna in any one pool, during at least 2 out of the 12 sampling dates, were selected for statistical analyses. For each sampling date, differences in abundance of each selected taxonomic group were examined among intertidal zones and among pools within zones using 2-factor nested analyses of variance. The effect of the nested factor (pool) was further examined within each zone (mid, high and splash).

The Shannon Diversity Index $\left(H^{\prime}\right)$ was calculated for each tidepool, for each sampling date, as $H^{\prime}=$ $-\sum_{i}^{n} P_{1} \ln P_{1}$, where $P_{i}$ is the proportion of the $i$ th taxonomic group in each tidepool. The lowest possible 
identification levels that were used as taxonomic groups to calculate $H^{\prime}$ varied among groups: harpacticoid copepods were assigned to planktonic (e.g. Microsetella rosea) and benthic (all others) groups; calanoid and cyclopoid copepods, rotifers and cladocerans were identified to genus; isopods and amphipods were identified to species; and nematodes, foraminiferans mites, polychaetes, ostracods and pycnogonids were not identified to any lower taxonomic level. Since the level of identification was consistent across all pools in all zones, the calculated index is used primarily as a comparative measure. $H^{\prime}$ was calculated for each pool using the average abundance of each taxonomic group for the 2 samples. Differences in the diversity index among intertidal zones were examined using a 2 -factor (zone and time) analysis of variance.

For all statistical analyses, the data were $\ln (x+1)$ transformed where heterogeneity of variance was detected using Cochran's test. A posteriori multiple comparisons of treatment means were done using Student-Newman-Keuls (SNK) tests. All statistical analyses were carried out using SYSTAT v. 5.1 (Wilkinson 1989) on a Macintosh SE 30 computer.

\section{RESULTS}

The abundance of 6 taxonomic groups was $>25 \%$ of total abundance in any one tidepool on any 2 sampling dates: harpacticoid copepodites and nauplii (Families Harpacticidae, Tisbidae, Thalestridae, Diosaccidae); calanoid copepodites and nauplii (the genera Acartia, Calanus, Paracalanus, Pseudocalanus and Temora at the sea surface and in the mid pools, and Eurytemora affinis in the splash pools); marine cladocerans (Podon polyphemoides and Evadne nordmanii); foraminiferans; marine rotifers (the genera Brachionus and Synchaeta); and nematodes (Appendix 1). Generally, the abundance of total hyperbenthos in the tidepools was low $\left(<10^{3}\right.$ ind. $\left.\mathrm{m}^{-3}\right)$ in early spring 1991 (March to May), increased in summer (up to $10^{7}$ ind. $\mathrm{m}^{-3}$ in the splash pools), decreased after October 1991, remained low through spring 1992, and increased again in summer 1992 (Fig. 1). The temporal trend in abundance in tidepools was similar to that observed at the sea surface. Temporal changes in the abundance of harpacticoid copepods and nematodes were similar to those observed for total hyperbenthos, both at the sea surface and in the pools (Figs. $2 \& 3$ ). The abundance of calanoid copepods was low at the sea surface and in the mid and high pools $\left(<10^{3}\right.$ ind $\left.\mathrm{m}^{-3}\right)$, and no pronounced temporal fluctuations were observed (Fig. 4). The abundance of this group was largest $\left(10^{4}\right.$ to $10^{5}$ ind. $\mathrm{m}^{-3}$ ) in the splash pools where it peaked in summer 1991 and 1992. Similarly, rotifers were present in low abundance $\left(<1000\right.$ ind. $\left.\mathrm{m}^{-3}\right)$ at the sea surface and in the mid pools in July and August 1992, but were abundant in the high and splash pools in summer 1991 and 1992 (up to $10^{6}$ ind. $\mathrm{m}^{-3}$ ) (Fig. 5). Cladocerans and foraminiferans were rare to absent at the sea surface and in tidepools for most of the year and no distinct temporal changes were observed. Pulses in abundance of these 2 groups were observed in some high and splash pools in late summer and late fall 1991 or early spring 1992, and at those times one or the other group made up $>25 \%$ of the hyperbenthic fauna in the pool (Figs. 6\&7).

The abundance of the different taxonomic groups of the hyperbenthos varied among intertidal zones only on 4 out of 12 sampling dates (Table 2). The abundance of total hyperbenthos was significantly different among zones in June 1991, July 1991, September 1991 and May 1992. Total hyperbenthos was significantly

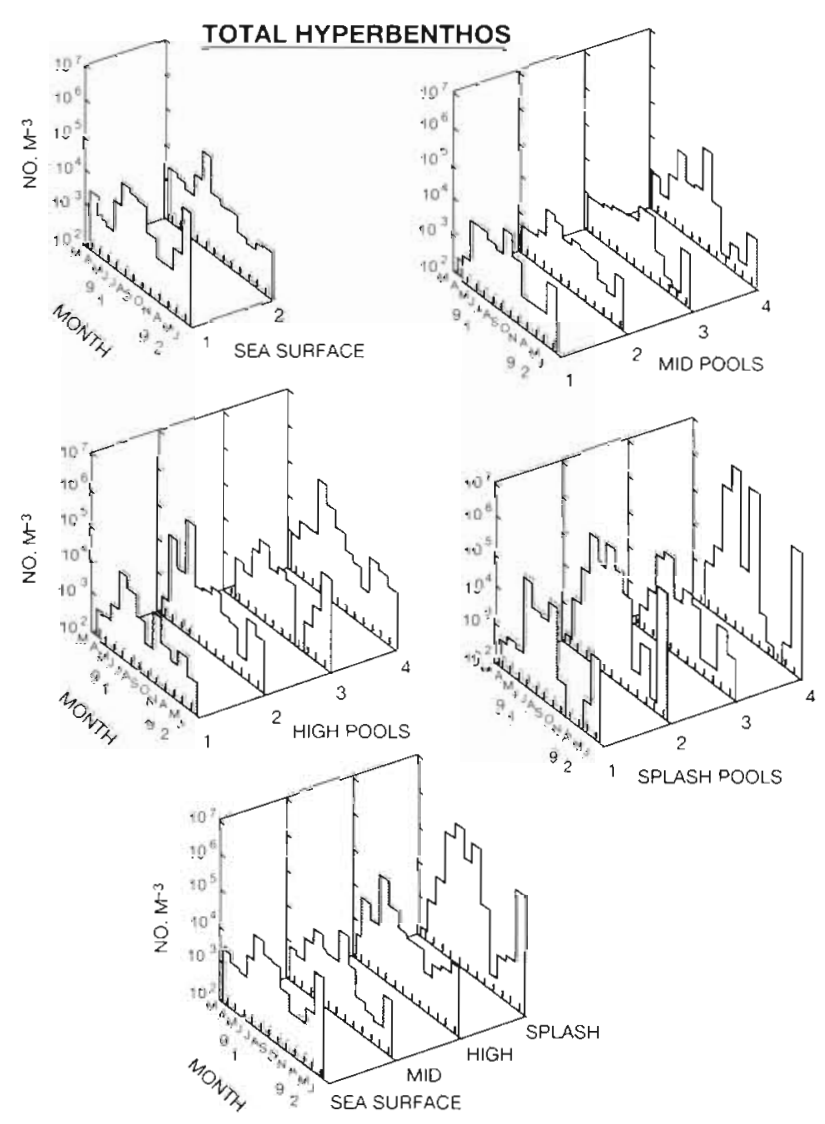

Fig. 1. Abundance of total hyperbenthos at the sea surface and in tidepools in 3 intertidal zones (mid, high and splash) at Cranberry Cove. Nova Scotia, sampled at monthly intervals between March and November 1991 and April and June 1992. Top 4 panels show abundance at each sea surface location and in each tidepool, at each zone. Bottom panel shows mean abundance at the sea surface (2 locations) and in each intertidal zone ( 4 tidepools) 


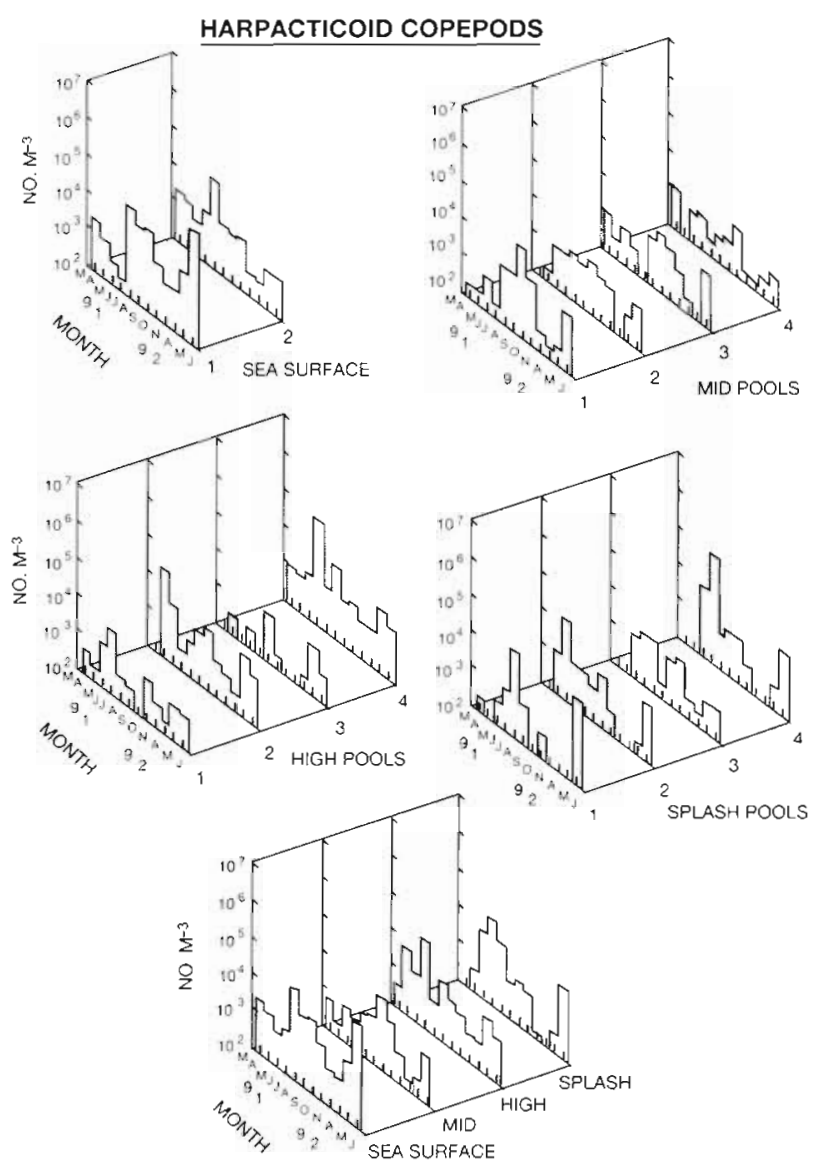

Fig. 2. Abundance of harpacticoid copepods at the sea surface and in tidepools in 3 intertidal zones (mid, high and splash) at Cranberry Cove, Nova Scotia, sampled at monthly intervals between March and November 1991 and April and June 1992. Top 4 panels show abundance at each sea surface location and in each tidepool, at each zone. Bottom panel shows mean abundance at the sea surface (2 locations) and in each intertidal zone (4 tidepools)

more abundant in splash pools than in mid pools in June 1991, in splash pools than in mid and high pools in July 1991, in splash pools than in high pools but not mid pools in September 1991, and in high pools than in mid pools but not splash pools in May 1992 (SNK tests, $\mathrm{p}<0.05$ ). Harpacticoid and calanoid copepods were significantly more abundant in high pools than in mid and splash pools in May 1992 (SNK tests, p<0.05). Nematodes were significantly more abundant in splash pools than in mid pools in July 1991 (SNK test, $\mathrm{p}<0.05$ ). Rotifers were significantly more abundant in splash pools than in mid pools in August 1991, and significantly more abundant in splash and high pools than in mid pools in September 1991 (SNK tests, $\mathrm{p}<0.05$ ).

The abundance of most taxonomic groups of the hyperbenthos varied significantly among tidepools within intertidal zones (Table 2). The abundance of total hyperbenthos varied significantly among splash pools from May to October 1991 and in June 1992, among high pools in June 1991 and 1992, and among mid pools in June and September 1991. The abundance of harpacticoid copepods varied significantly among tidepools in the high zone in June, July and October 1991. Harpacticoid copepods also showed a significant pool effect in the high zone in September 1991, although the combined pool effect for all zones was not significant. The abundance of nematodes varied significantly among pools in all zones in June 1991. Nematode abundance also varied significantly among mid pools in September 1991 and among splash pools in July 1992, although the combined pool effect for all zones was not significant at these times. The abundance of calanoid copepods varied significantly
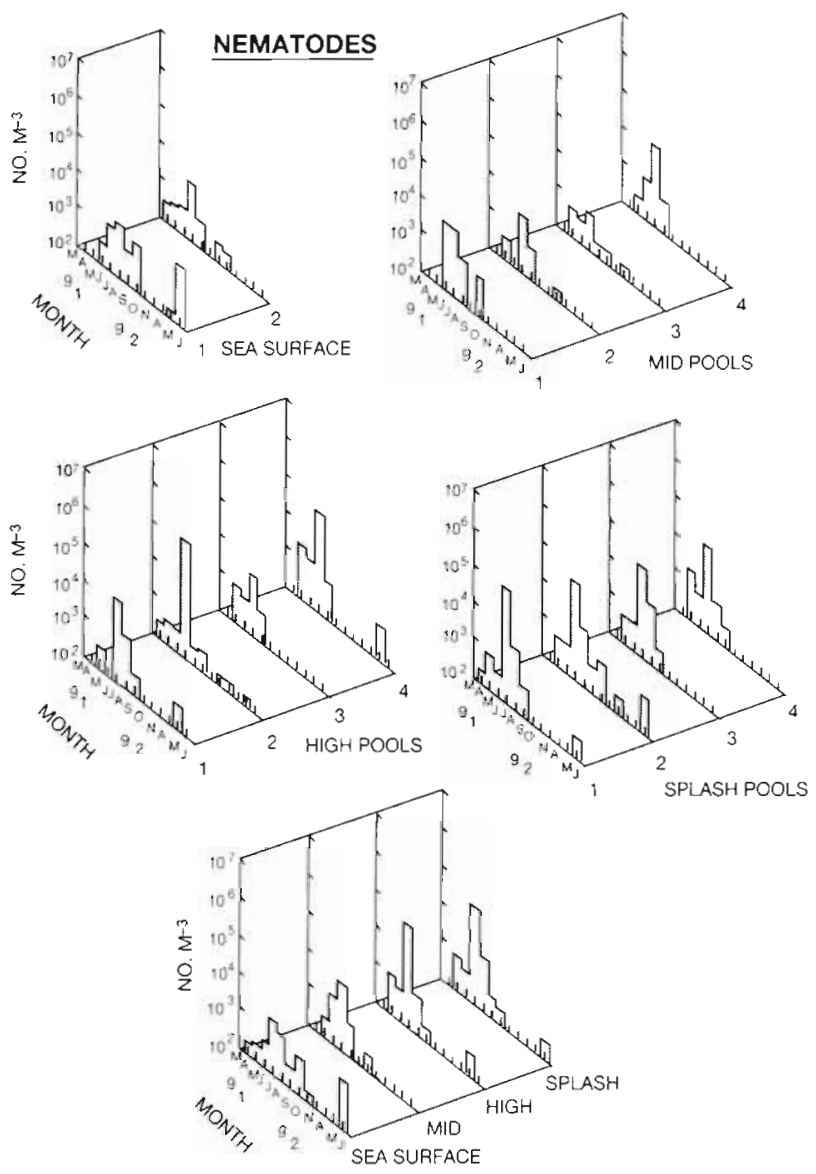

Fig. 3. Abundance of nematodes at the sea surface and in tidepools in 3 intertidal zones (mid, high and splash) at Cranberry Cove, Nova Scotia, sampled at monthly intervals between March and November 1991 and April and June 1992. Top 4 panels show abundance at each sea surface location and in each tidepool, at each zone. Bottom panel shows mean abundance at the sea surface (2 locations) and in each intertidal zone ( 4 tidepools) 

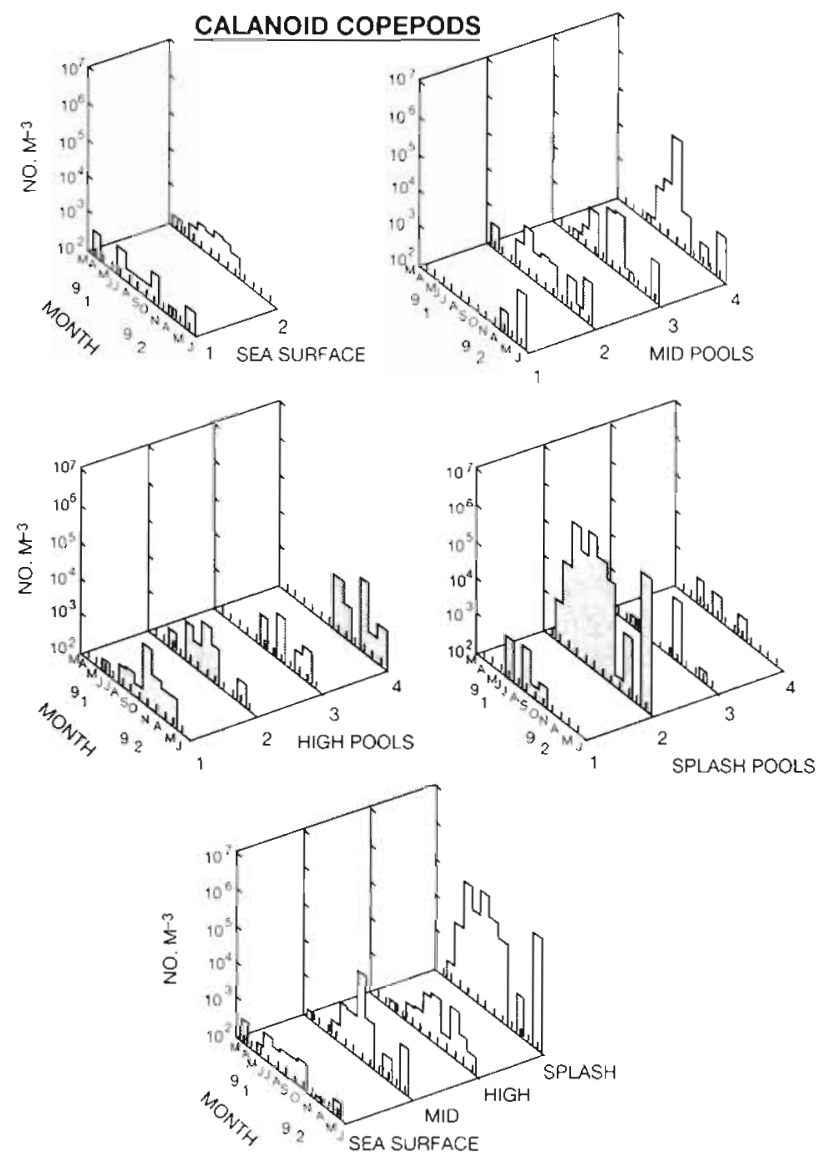

Fig. 4. Abundance of calanoid copepods at the sea surface and in tidepools in 3 intertidal zones (mid, high and splash) at Cranberry Cove, Nova Scotia, sampled at monthly intervals between March and November 1991 and April and June 1992. Top 4 panels show abundance at each sea surface location and in each tidepool, at each zone. Bottom panel shows mean abundance at the sea surface (2 locations) and in each intertidal zone (4 tidepools)

among splash pools from June to September 1991 and in June 1992, among high pools in July 1991 and June 1992, and among mid pools in September 1991. The abundance of rotifers varied significantly among splash pools from May to July and in September 1991. among high pools in June, July and September 1991 and in June 1992, and among mid pools in June 1991. The abundance of marine cladocerans varied significantly among splash pools in May 1992. Cladoceran abundance also differed significantly among high pools in October 1991 although the combined pool effect for all zones was not significant. The abundance of foraminiferans was significantly different among mid pools in June 1991 and, although the combined pool effect was not significant, the abundance of this group varied significantly among high pools in May 1992.
The Shannon Diversity Index $\left(H^{\prime}\right)$ varied significantly among zones $\left(F_{2.108}=12.028, \mathrm{p}<0.001\right)$ and over time $\left(F_{11,108}=2.841, \mathrm{p}<0.01\right)$ (Fig. $\left.8 \mathrm{~A}\right)$, and there was no significant interaction between zone and time effects on $H^{\prime}\left(F_{22,108}=0.962, \mathrm{p}>0.05\right) . H^{\prime}$ was significantly smaller in splash pools than in mid and high pools ( $S N K$ test, $p<0.05$ ). There were no consistent temporal trends in $H^{\prime}$ in the tidepools (Fig. 8B). At the sea surface, diversity increased between March and October 1991, decreased after October and started increasing again after April 1992.

\section{DISCUSSION}

The major components of the hyperbenthos in this study represented different functional groups. Cala-
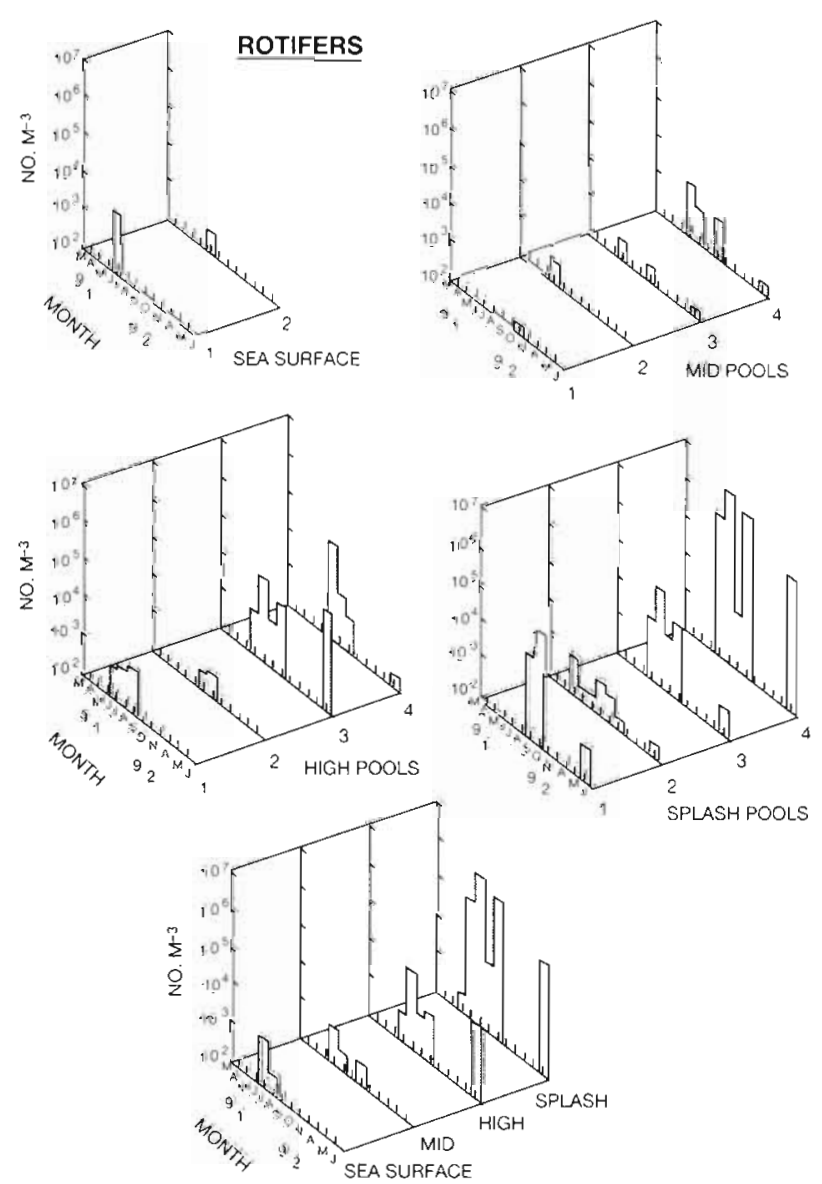

Fig. 5. Abundance of rotifers at the sea surface and in tidepools in 3 intertidal zones (mid, high and splash) at Cranberry Cove, Nova Scotia, sampled at monthly intervals between March and November 1991 and April and June 1992. Top 4 panels show abundance at each sea surface location and in each tidepool, at each zone. Bottom panel shows mean abundance at the sea surface (2 locations) and in each intertidal zone ( 4 tidepools) 

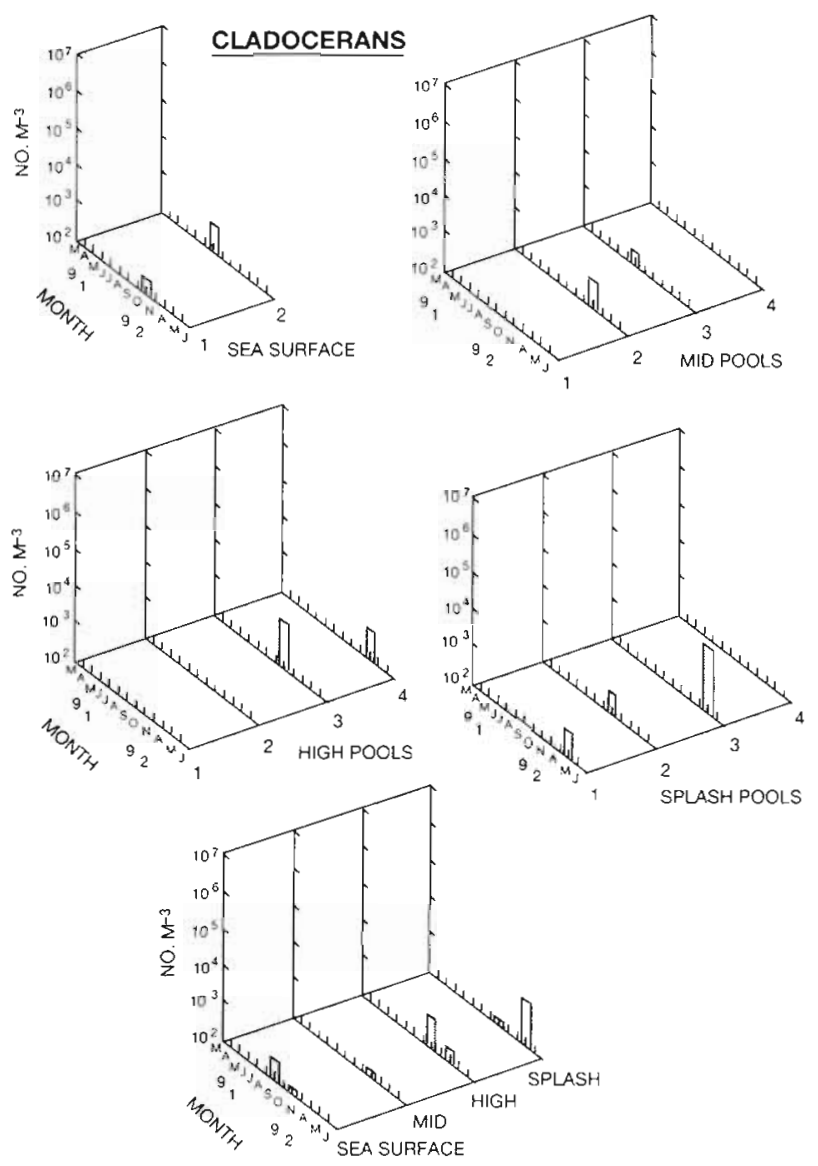

Fig. 6. Abundance of cladocerans at the sea surface and in tidepools in 3 intertidal zones (mid, high and splash) at Cranberry Cove, Nova Scotia, sampled at monthly intervals between March and November 1991 and April and June 1992. Top 4 panels show abundance at each sea surface location and in each tidepool, at each zone. Bottom panel shows mean abundance at the sea surface (2 locations) and in each intertidal zone (4 tidepools)

noid copepods and cladocerans filter feed in the water column and spend most of their time swimming. Rotifers become attached to hard surfaces but filter feed in the water column. Harpacticoid copepods, nematodes and foraminiferans feed on hard surfaces and spend less time swimming than calanoid copepods and cladocerans. Most of these groups generally showed temporal patterns of abundance that suggest seasonality, increasing between late spring and late summer of both years with increasing water temperature, and decreasing in the late fall and over the winter 1991, both at the sea surface and in the tidepools. The diversity also tended to increase from early spring to midsummer of both years as the different taxa became progressively more abundant, and was smaller in the late fall and early winter with decreasing faunal abundance.
The hyperbenthos of tidepools can be assigned to 3 categories based on temporal patterns in their abundance in tidepools relative to the sea surface. Harpacticoid copepods and nematodes showed temporal changes in abundance that were similar at the sea surface and in the pools, suggesting that their abundance in tidepools was determined either by tidal input or by the same factors as in the surrounding seawater. Calanoid copepods and rotifers were present in low abundance and showed no temporal fluctuations at the sea surface or in the mid and high pools, but were abundant in summer of both years and early fall 1991 in the splash pools. The abundance of these 2 groups in splash pools, therefore, was not set by daily tidal input and may have been determined by founder effects or competitive exclusion. Cladocerans and foraminiferans showed pulses in abundance in the tidepools in
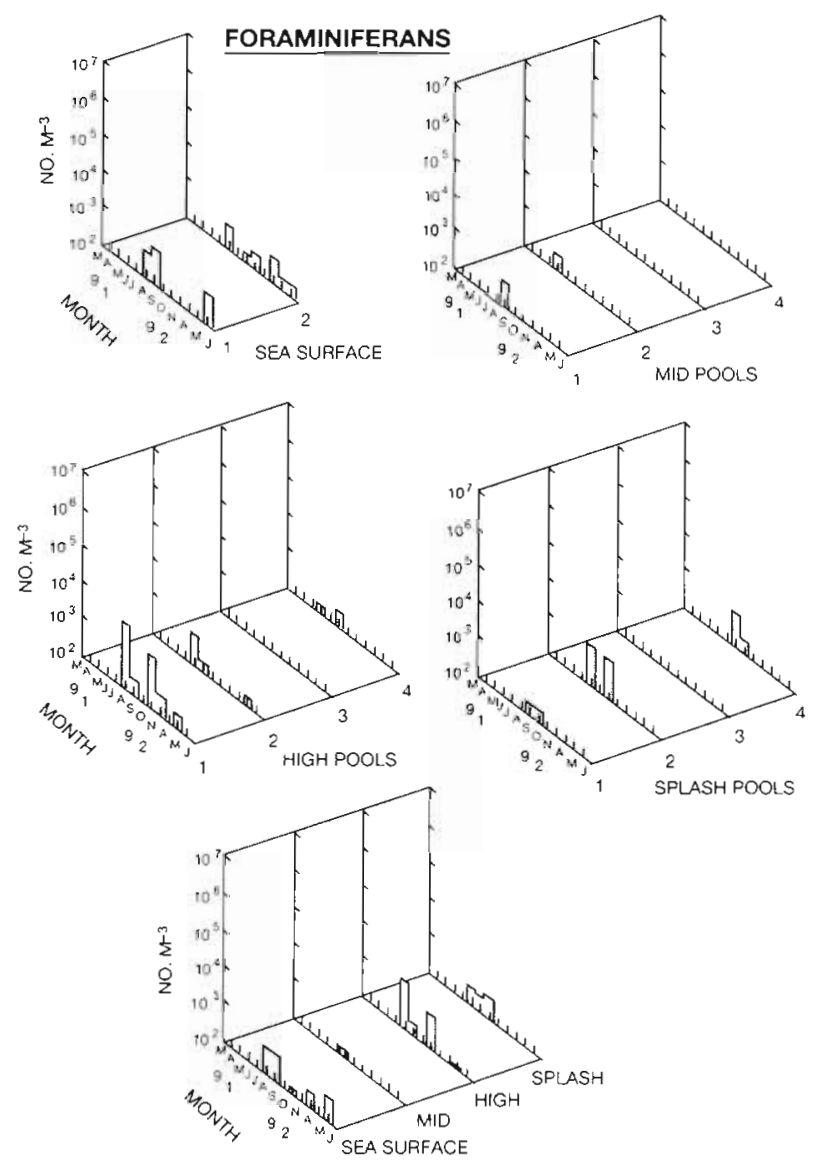

Fig. 7. Abundance of foraminiferans at the sea surface and in tidepools in 3 intertidal zones (mid, high and splash) at Cranberry Cove, Nova Scotia, sampled at monthly intervals between March and November 1991 and April and June 1992. Top 4 panels show abundance at each sea surface location and in each tidepool, at each zone. Bottom panel shows mean abundance at the sea surface (2 locations) and in each intertidal zone (4 tidepools) 
Table 2. Analyses of variance of the abundance of different groups of hyperbenthos (ind. $\mathrm{m}^{-3}$ ) for 12 sampling periods between March 1991 and June 1992. Factors are intertidal zone $(Z)$ and pool (nested within zone) $[P(Z)]$; degrees of freedom: $F_{P_{i}} Z=9,12$ $F_{Z}=2,9$ if $P_{P(2)}<0.250$ and $F_{Z}=2,21$ if $P_{P(Z)}>0.250 . \cdots p<0.001 ; \cdots p<0.01 ; \mathrm{p}<0.05 ; \mathrm{ns}: \mathrm{p}>0.05$

\begin{tabular}{|c|c|c|c|c|c|c|c|c|c|c|c|c|c|}
\hline \multirow[t]{2}{*}{ Variable } & \multirow[t]{2}{*}{ Factor } & \multicolumn{2}{|c|}{17 Mar 1991} & \multicolumn{2}{|c|}{13 Apr 1991} & \multicolumn{2}{|c|}{13 May 1991} & \multicolumn{2}{|c|}{7 Jun 1991} & \multicolumn{2}{|c|}{12 Jul 1991} & \multicolumn{2}{|c|}{22 Aug 1991} \\
\hline & & $F$ & $\mathrm{p}$ & $F$ & p & F & $\mathrm{p}$ & F & $\mathrm{p}$ & $F$ & $\mathrm{p}$ & $F$ & $\mathrm{p}$ \\
\hline \multirow[t]{2}{*}{ Harpacticoids } & $P(Z)$ & 0.90 & ns & 2.64 & ns & 2.61 & ns & 3.68 & $\cdot$ & 3.88 & $0.016^{\circ}$ & 1.79 & ns \\
\hline & $Z:$ & 1.49 & ns & 2.11 & ns & 0.78 & ns & 0.61 & ns & 1.91 & ns & 0.56 & ns \\
\hline \multirow[t]{2}{*}{ Nematodes } & $P(Z):$ & 1.39 & ns & 1.04 & ns & 1.13 & ns & \multirow{2}{*}{\multicolumn{2}{|c|}{$\begin{array}{cc}8.60 & 0.001 \cdots \\
4.14 & 0.053\end{array}$}} & 0.76 & ns & 0.38 & ns \\
\hline & $Z:$ & 0.71 & ns & 0.98 & ns & 0.74 & ns & & & 3.63 & $\cdot$ & 2.15 & ns \\
\hline \multirow[t]{2}{*}{ Calanoids } & $P(Z):$ & 2.08 & ns & 2.69 & 0.056 & 2.77 & ns & 6.56 & $\cdots$ & 4.49 & $0.009 \cdots$ & 3.84 & $0.017^{\circ}$ \\
\hline & $Z:$ & 1.36 & ns & 0.85 & ns & 0.88 & ns & 1.43 & ns & 1.91 & ns & 0.09 & ns \\
\hline \multirow[t]{2}{*}{ Rotifers } & $P(Z):$ & \multirow{2}{*}{\multicolumn{2}{|c|}{$\begin{array}{l}\text { In one pool } \\
\text { High zone }\end{array}$}} & \multirow{2}{*}{\multicolumn{2}{|c|}{$\begin{array}{l}\text { Absent } \\
\text { Absent }\end{array}$}} & \multicolumn{2}{|c|}{$38.60 .000 \cdots$} & \multicolumn{2}{|c|}{$8.060 .001 \cdots$} & \multicolumn{2}{|c|}{$11.30 .000 \cdots$} & \multirow{2}{*}{\multicolumn{2}{|c|}{$\begin{array}{cc}1.52 & \text { ns } \\
50.0 & 0.000\end{array}$}} \\
\hline & $Z:$ & & & & & 1.15 & ns & 0.48 & ns & 0.79 & $\mathrm{~ns}$ & & \\
\hline & $\begin{array}{l}P(Z): \\
Z:\end{array}$ & \multicolumn{2}{|c|}{$\begin{array}{l}\text { Absent } \\
\text { Absent }\end{array}$} & \multicolumn{2}{|c|}{$\begin{array}{l}\text { Absent } \\
\text { Absent }\end{array}$} & \multicolumn{2}{|c|}{$\begin{array}{l}\text { Absent } \\
\text { Absent }\end{array}$} & \multicolumn{2}{|c|}{$\begin{array}{l}\text { Absent } \\
\text { Absent }\end{array}$} & \multicolumn{2}{|c|}{$\begin{array}{l}\text { Absent } \\
\text { Absent }\end{array}$} & \multicolumn{2}{|c|}{$\begin{array}{l}\text { In one pool } \\
\text { Mid zone }\end{array}$} \\
\hline \multirow{2}{*}{ Foraminiferans } & $P(Z):$ & $\mathrm{Ab}$ & ent & Abs & ent & $\mathrm{Ab}$ & & 2.97 & ${ }^{\circ}$ & 1.73 & $\mathrm{~ns}$ & 1.15 & ns \\
\hline & $Z:$ & $\mathrm{Ab}$ & ent & $\mathrm{Abs}$ & ent & $\mathrm{Ab}$ & & 0.17 & ns & 2.70 & ns & 0.13 & ns \\
\hline Total & $P(Z):$ & 0.75 & ns & 1.90 & ns & 3.30 & $\cdot$ & 22.5 & $.000 \cdots$ & 6.28 & $\because$ & 7.02 & $0.001 \cdots$ \\
\hline & $Z:$ & 1.98 & ns & 0.25 & ns & 0.57 & ns & 5.87 & $\cdot$ & 7.49 & $0.012^{\circ}$ & 2.53 & ns \\
\hline & & $21 \mathrm{Se}$ & 1991 & 9 Oct & 1991 & $17 \mathrm{No}_{0}$ & 1991 & $8 \mathrm{Apr}$ & 1992 & 6 May & y 1992 & $26 \mathrm{Jur}$ & n 1992 \\
\hline & & $F$ & $\mathrm{p}$ & $F$ & $\mathrm{p}$ & $F$ & $\mathrm{p}$ & $F$ & $\mathrm{p}$ & $F$ & $\mathrm{p}$ & $F$ & $\mathrm{p}$ \\
\hline Harpacticoids & $P(Z):$ & 2.23 & 0.10 & 2.95 & • & 1.78 & ns & 0.88 & ns & 0.45 & ns & 1.06 & ns \\
\hline & $Z:$ & 0.87 & ns & 1.41 & ns & 0.77 & ns & 2.43 & ns & 4.55 & $\cdot$ & 0.09 & ns \\
\hline Nematodes & $P(Z):$ & 2.51 & 0.069 & 1.72 & ns & 1.45 & ns & 0.78 & ns & 1.63 & ns & 2.35 & 0.086 \\
\hline & $Z:$ & 0.24 & ns & 1.03 & ns & 0.46 & ns & 1.11 & ns & 3.49 & ns & 0.71 & ns \\
\hline Calanoids & $P(Z):$ & 7.12 & $0.001 \cdots$ & 1.38 & ns & 0.59 & ns & 2.35 & ns & 0.39 & ns & 13.6 & $0.000^{\cdots}$ \\
\hline & $Z$ & 0.49 & NS & 0.83 & ns & 0.50 & ns & 0.62 & ns & 9.04 & $\cdots$ & 1.66 & $\mathrm{~ns}$ \\
\hline Rotifers & $P(Z):$ & 3.19 & $\cdot$ & 1.00 & ns & $\mathrm{Ab}$ & & Abs & ent & In on & e pool & 4.05 & $0.014^{\circ}$ \\
\hline & $Z:$ & 4.84 & $\cdot$ & 0.50 & $\mathrm{~ns}$ & $A b$ & & Abs & ent & Splast & h zone & 3.21 & ns \\
\hline Cladocerans & $P(Z):$ & Abs & ent & 1.99 & ns & In on & pool & 0.68 & ns & 3.23 & $\cdot$ & Abs & sent \\
\hline & $Z$ & Abs & ent & 0.03 & ns & Mid & ne & 2.26 & ns & 1.69 & ns & $\mathrm{Abs}$ & $\operatorname{sen} t$ \\
\hline Foraminiferans & $P(Z):$ & 0.54 & ns & In one & pool & 1.00 & ns & $\mathrm{Abs}$ & ent & 2.64 & 0.060 & 1.00 & ns \\
\hline & $Z:$ & 1.34 & ns & High & zone & 0.51 & ns & $A b s$ & ent & 2.67 & ns & 0.00 & ns \\
\hline Total & $P(Z):$ & 5.51 & $\because$ & 3.55 & $\cdot$ & 1.19 & ns & 1.57 & ns & 0.81 & ns & 4.73 & $\cdots$ \\
\hline & $Z$ & 5.15 & $\cdot$ & 0.05 & ns & 1.79 & ns & 0.97 & ns & 3.55 & $\cdot$ & 1.80 & ns \\
\hline
\end{tabular}

the late summer and early fall 1991. In late summer, these pulses corresponded to pulses at the sea surface, suggesting that they reflected tidal input. In late fall, however, the pulses in the tidepools were not associated with changes in abundance of these groups at the sea surface and, therefore, were independent of tidal input.

The number of taxonomic groups of hyperbenthos decreased with a decrease in flushing rate of the pools. For example, 5 genera of calanoid copepods (Acartia, Calanus, Pseudocalanus, Paracalanus, Temora) were found in mid and high pools, whereas Eurytemora affinis was the only species of calanoid copepod found in splash pools. Other studies also have shown that macroalgal and macroinvertebrate species diversity decreases in tidepools with increasing intertidal height
(Gustavsson 1972, Femino \& Mathieson 1980, Huggett \& Griffiths 1986, Lawrence \& McClintock 1987, Wolfe \& Harlin 1988, Kooistra et al. 1989). Decreased diversity in pools that are located high on the shore may be due to increased physiological stress during extended periods of isolation from tidal input. This can result in low food abundance, high temperature and increased salinity due to evaporation in summer, and freezing and increased salinity in winter. Such adverse conditions can constrain a number of organisms to pools that are located lower on the shore, and receive regular tidal input that resets the physical environment. The fauna of pools in the high intertidal and splash zones, therefore, may be restricted to those taxonomic groups that can withstand the extreme variations in physical conditions. 

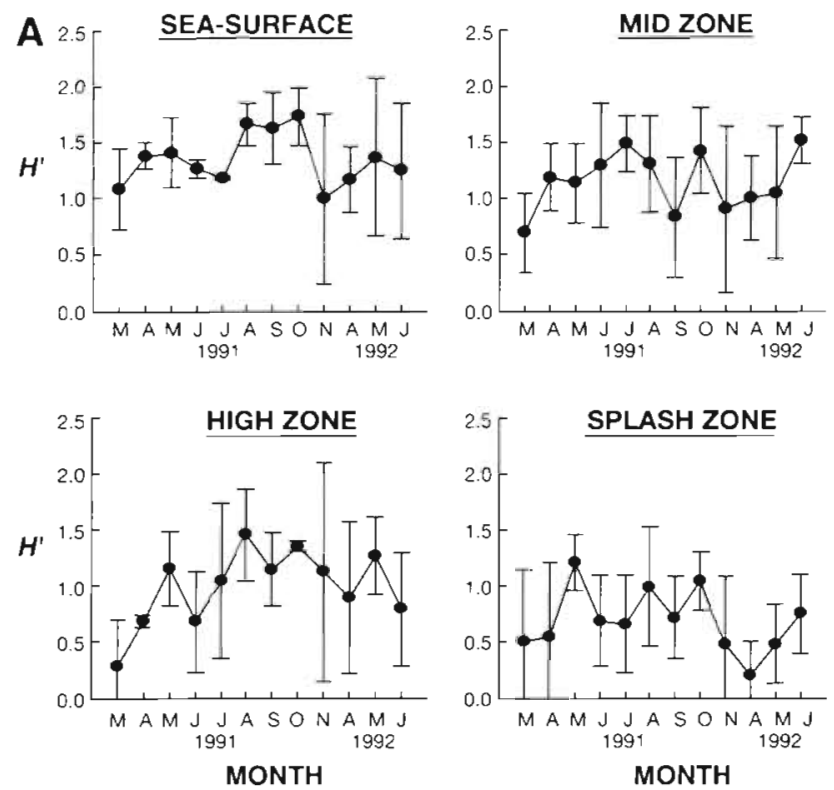

B

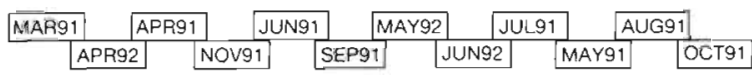

Fig. 8. (A) Changes in the Shannon Diversity Indices of faunal hyperbenthic communities at the sea surface and in tidepools in 3 intertidal zones (mid, high and splash) at Cranberry Cove, Nova Scotia, sampled at monthly intervals between March and November 1991 and April and June 1992. Error bars are standard deviations ( $\mathrm{n}=2$ at the sea surface and $\mathrm{n}=4$ in the mid, high and splash zones). (B) StudentNewman-Keuls test for changes in the diversity indices over the 12 sampling dates. Bars connect dates among which diversity indices were not significantly different at the 0.05 level of significance

The abundance of the total hyperbenthos differed significantly among intertidal zones only on 4 sampling dates. On 3 of those dates, abundance was greatest in splash pools, and on the other, abundance was greatest in the high pools (although they were not statistically different from splash pools). In particular, the abundance of calanoid and harpacticoid copepods, nematodes and rotifers was greater in high and/or splash pools on 1 or 2 sampling dates. These results are in partial agreement with previous studies. Fraser (1936), Ganning (1971) and Dethier (1980) showed that the abundance of harpacticoid copepods increases in tidepools of increasing intertidal height. However, Fraser (1936) found that the abundance of calanoid copepods decreased in the higher intertidal zones in pools on the Isle of Man, UK. This was not the case in our study mainly because a large population of Eurytemora affinis occu- pied one of the splash pools and was particularly abundant in summer of both years. To our knowledge, the only record of rotifers in tidepools was provided by Ganning (1971) who found these organisms in one of the lower pools in his study (probably similar to our mid pools) and in a higher pool in midsummer.

The small number of significant zone effects on the abundance of hyperbenthos can be explained by the large variability among tidepools within each zone. We detected significant pool effects for most groups on most sampling dates particularly among high or splash pools. For example, the abundance of harpacticoid copepods in 2 of the high pools was consistently less than in the other 2 . The calanoid copepod Eurytemora affinis and rotifers each reached abundances in the order of $10^{6}$ ind. $\mathrm{m}^{-3}$ in 1 splash pool but were virtually absent in all 3 other pools. A pulse in the abundance of cladocerans occurred only in 1 pool (but on different dates) in both the high intertidal and the splash zones. Similarly, different pulses in the abundance of foraminiferans occurred only in 1 pool both in the mid and the high intertidal zones.

Despite harsh physical conditions, splash pools harbour populations of certain tolerant groups of organisms with densities of up to 3 orders of magnitude higher than at the sea surface. The dominant species vary among splash pools but the populations are persistent in the particular pools between years. The populations that inhabit splash pools are probably endemic and do not depend upon tidal input to become re-established every year. Furthermore, the low flushing frequency in the high and splash pools may enable the persistence of these populations which may become diluted or replaced in tidepools lower on the shore. Although the abundance of hyperbenthos in tidepools does not show a consistent zonation along the intertidal gradient, variability in abundance increases among pools with increasing intertidal height. The variability in the dominant taxa among splash pools may be the result of a founder effect early in the establishment of tidepool communities. Alternatively, it may reflect variability in local environmental conditions which favour different competitively dominant taxa in different tidepools.

Acknowledgements. We thank Brian Dixon, Heather Hunt, Laurence McCook, Todd Minchinton, Ellen Pedersen and Don Webb for assisting in sample collection. We also thank Don Webb for help with faunal identification. Drs B. G. Hatcher and D. G. Webb critically read earlier drafts of the manuscript. A.M. was supported by an 'Alexander S. Onassis' Public Benefit Foundation Postgraduate Scholarship and scholarships from the Dalhousie Faculty of Graduate Studies. The research was funded by an NSERC operating grant to R.E.S. 
Appendix 1. List of taxonomic groups of hyperbenthos identified in this study and present at the sea surface and in the tidepools on any sampling date between March 1991 and June 1992

\begin{tabular}{|c|c|c|c|c|c|c|c|c|c|c|c|c|c|}
\hline \multirow[t]{2}{*}{ Taxonomic group } & \multirow[t]{2}{*}{ Sea } & \multicolumn{4}{|c|}{ Mid pools } & \multicolumn{4}{|c|}{ High pools } & \multicolumn{4}{|c|}{ Splash pools } \\
\hline & & 1 & 2 & 3 & 4 & 1 & 2 & 3 & 4 & 1 & 2 & 3 & 4 \\
\hline Acarina & $\checkmark$ & $\checkmark$ & $\checkmark$ & $\checkmark$ & & $\checkmark$ & $\checkmark$ & $\checkmark$ & $\checkmark$ & $\checkmark$ & $\checkmark$ & & $\checkmark$ \\
\hline \multicolumn{14}{|l|}{ Amphipods } \\
\hline Amphithoe rubricata (Montagu) & $\checkmark$ & $\checkmark$ & & & & & & $\checkmark$ & & & $\boldsymbol{v}$ & & \\
\hline Casco bigelowi (Blake) & & & & & $\checkmark$ & & & & & & & & \\
\hline Corophium volutator (Pallas) & $\checkmark$ & & & & $\checkmark$ & $\checkmark$ & $\checkmark$ & & & & & $\checkmark$ & \\
\hline Gammarus oceanicus Segerstråle & $\checkmark$ & $\checkmark$ & $\boldsymbol{\nu}$ & & & & & & & $\sim$ & $\checkmark$ & & \\
\hline Gammarus tigrinus Sexton & $\checkmark$ & & & $\checkmark$ & $\checkmark$ & & $\checkmark$ & & & $\checkmark$ & $\checkmark$ & & \\
\hline Marinogammarus finmarchicus Dahl & $\checkmark$ & & $\checkmark$ & & $\checkmark$ & & & & & & $\checkmark$ & & \\
\hline Pontogeneia inermis (Kröyer) & $\checkmark$ & $\checkmark$ & & & & & & & & & & & \\
\hline \multicolumn{14}{|l|}{ Calanoid copepods } \\
\hline Acartia sp. & $\checkmark$ & $\checkmark$ & $\checkmark$ & $\checkmark$ & $\checkmark$ & $\checkmark$ & & $\checkmark$ & $\checkmark$ & $\checkmark$ & & & \\
\hline Calanus sp. & $\checkmark$ & $\checkmark$ & $\checkmark$ & $\checkmark$ & & $\checkmark$ & & $\checkmark$ & & & & $\checkmark$ & \\
\hline Eurytemora affinis (Poppe) & $\checkmark$ & & $\checkmark$ & $\checkmark$ & $\checkmark$ & $\checkmark$ & $\checkmark$ & $\checkmark$ & $\checkmark$ & $\checkmark$ & $\checkmark$ & & $\checkmark$ \\
\hline Paracalanus sp. & $\checkmark$ & $\checkmark$ & $\checkmark$ & $\checkmark$ & $\checkmark$ & & & & & & & & \\
\hline$p_{\text {seudocalanus } \mathrm{sp}}$ & $\checkmark$ & $\checkmark$ & $\checkmark$ & $\checkmark$ & $\checkmark$ & $\boldsymbol{v}$ & $\sim$ & $\boldsymbol{v}$ & & & & & \\
\hline Temora longicornis (Müller) & $\boldsymbol{\sim}$ & & $\checkmark$ & $\checkmark$ & $\checkmark$ & & $\checkmark$ & & & $\checkmark$ & & & \\
\hline T. stylifera (Dana) & & $\checkmark$ & & & & & & & & & & & \\
\hline Calanoid nauplii & $\checkmark$ & $\checkmark$ & $\checkmark$ & $\sim$ & $\checkmark$ & $\checkmark$ & $\checkmark$ & $\checkmark$ & $\checkmark$ & $\checkmark$ & $\checkmark$ & $\checkmark$ & $\checkmark$ \\
\hline \multicolumn{14}{|l|}{ Cirripedia } \\
\hline Semibalanus balanoides (L.) nauplii & & & & & & & & & & $\checkmark$ & & $\checkmark$ & \\
\hline \multicolumn{14}{|l|}{ Cladocerans } \\
\hline Evadne nordmanil Loven & $\checkmark$ & $\checkmark$ & $\checkmark$ & $\checkmark$ & $\checkmark$ & $\checkmark$ & $\checkmark$ & & $\checkmark$ & $\checkmark$ & $\checkmark$ & $\checkmark$ & $\checkmark$ \\
\hline Podon polyphemoides Leuckart & $\checkmark$ & $\sim$ & $\checkmark$ & $\checkmark$ & $\checkmark$ & $\checkmark$ & $\checkmark$ & & $\checkmark$ & $\checkmark$ & $\checkmark$ & $\checkmark$ & $\checkmark$ \\
\hline \multicolumn{14}{|l|}{ Cyclopoids } \\
\hline Oithona similis Claus & $\checkmark$ & $\checkmark$ & $\checkmark$ & $\checkmark$ & $\checkmark$ & $\checkmark$ & $\checkmark$ & $\checkmark$ & $\checkmark$ & $\checkmark$ & & $\checkmark$ & $\checkmark$ \\
\hline Foraminiferans & $\checkmark$ & $\sim$ & $\checkmark$ & & $\checkmark$ & $\checkmark$ & $\checkmark$ & & $\checkmark$ & $\checkmark$ & $\checkmark$ & $\checkmark$ & $\checkmark$ \\
\hline \multicolumn{14}{|l|}{ Harpacticoid copepods } \\
\hline Microsetella rosea (Dana) & $\checkmark$ & $\checkmark$ & $\checkmark$ & $\checkmark$ & $\checkmark$ & & $\boldsymbol{v}$ & $\checkmark$ & $\checkmark$ & & & $\sim$ & \\
\hline Other harpacticoid copepods & $\checkmark$ & $\checkmark$ & $\checkmark$ & $r$ & $\checkmark$ & $\checkmark$ & $\checkmark$ & $\checkmark$ & $\boldsymbol{v}$ & $\checkmark$ & $\sim$ & $\checkmark$ & $\checkmark$ \\
\hline Harpacticoid nauplii & $\checkmark$ & $\checkmark$ & $\checkmark$ & $\checkmark$ & $\checkmark$ & $\checkmark$ & $\checkmark$ & $\checkmark$ & $\checkmark$ & $\checkmark$ & $\checkmark$ & $\checkmark$ & $\checkmark$ \\
\hline \multicolumn{14}{|l|}{ Isopods } \\
\hline Idotea balthica (Pallas) & $\checkmark$ & $\checkmark$ & & & & & & & & & & & $\checkmark$ \\
\hline Idotea phosphorea Harger & $\checkmark$ & & & & & & $\checkmark$ & & & & & & $\boldsymbol{v}$ \\
\hline Jaera marina (Fabricius) & $\checkmark$ & $\checkmark$ & $\checkmark$ & & & $\checkmark$ & $\checkmark$ & & $\checkmark$ & & $\checkmark$ & $\checkmark$ & $\checkmark$ \\
\hline Nematodes & $\checkmark$ & $\checkmark$ & $\checkmark$ & $\checkmark$ & $\checkmark$ & $\checkmark$ & $\checkmark$ & $\checkmark$ & $\checkmark$ & $\checkmark$ & $\checkmark$ & $\checkmark$ & $\checkmark$ \\
\hline Ostracods & $\checkmark$ & $\checkmark$ & $\checkmark$ & $\checkmark$ & $\checkmark$ & $\checkmark$ & $\checkmark$ & & $\checkmark$ & $\checkmark$ & $\checkmark$ & $\checkmark$ & $\checkmark$ \\
\hline Polychaetes & $\checkmark$ & $\checkmark$ & $\checkmark$ & & $\checkmark$ & & & & $\checkmark$ & & $\checkmark$ & & $\checkmark$ \\
\hline Pycnogonids & $\checkmark$ & $\checkmark$ & & $\checkmark$ & $\checkmark$ & $\checkmark$ & & $\checkmark$ & $\checkmark$ & & $\checkmark$ & $\checkmark$ & \\
\hline \multicolumn{14}{|l|}{ Rotifers } \\
\hline Brachionus spp. & $\checkmark$ & $\checkmark$ & $\checkmark$ & $\checkmark$ & $r$ & $\checkmark$ & $\checkmark$ & $\checkmark$ & $\sim$ & $\checkmark$ & & $\checkmark$ & $\checkmark$ \\
\hline Synchaeta spp. & $\checkmark$ & $\checkmark$ & $\checkmark$ & $\checkmark$ & $\boldsymbol{v}$ & $\checkmark$ & $\checkmark$ & $\checkmark$ & $\checkmark$ & $\checkmark$ & $\checkmark$ & $\checkmark$ & $\checkmark$ \\
\hline
\end{tabular}

\section{LITERATURE CITED}

Barnes, R. D. (1980). Invertebrate zoology. Saunders College, Philadelphia

Beyer, F. (1958) A new, bottom-living trachymedusa from the Oslo fjord. Nytt Mag. Zool. 6: 121-143

Brinkhurst, R. O., Linkletter, L. E., Lord, E. I., Connors, S. A., Dadswell, M. J. (1976). A preliminary guide to the littoral and sublittoral invertebrates of Passamaquoddy Bay. Identification Center, Department of the Environment, Fisheries and Marine Service, Biological Station, St. Andrews, NB
Dean, R. L., Connell, J. H. (1987a). Marine invertebrates in algal succession. II. Tests of hypotheses to explain changes in diversity with succession. J. exp. Mar. Biol Ecol. 109; $217-247$

Dean, R. L., Connell, J. H. (1987b). Marine invertebrates in algal succession. III. Mechanisms linking habitat complexity with diversity. J. exp. mar. Biol. Ecol. 109: 249-273

Dethier, M. N. (1980). Tidepools as refuges: predation and the limits of the harpacticoid copepod Tigriopus californicus (Baker). J. exp. mar. Biol. Ecol. 42: 99-111

Femino, R. J., Mathieson, A. C. (1980). Investigations of New England marine algae IV The ecology and seasonal suc- 
cession of tide pool algae at Bald Head Cliff, York, Maine, USA. Botanica mar. 23: 319-332

Fraser, J. H. (1936). The distribution of rock pool copepoda according to tidal level. J. Anim. Ecol. 5: 1936

Ganning, B. (1971). Studies of chemical, physical and biological conditions in Swedish rockpool ecosystems. Ophelia 9: $51-105$

Gardner, G. A., Szabo, I. (1982). British Columbia pelagic marine copepoda: an identification manual and annotated bibliography. Spec. Publ. Can. Fish. Aquat. Sci. 62

Gibbons, M. J. (1988). The impact of sediment accumulations, relative habitat complexity and elevation on rocky shore meiofauna. J. exp. mar. Biol. Ecol. 122: 225-241

Gibbons, M. J. (1989). Tidal migration of Porcellidium (Copepoda: Harpacticoida) on fronds of the rocky shore alga Gigartina radual (Esper) J. Agardh (Gigartinales: Rhodophyta). S. Afr. J. mar. Sci. 8: 3-7

Goss-Custard, S., Jones, J., Kitching, J. A., Norton, T. A. (1979). Tidepools of Carrigathorna and Barloge Creek. Phil. Trans. R. Soc. Lond. B 287: 1-44

Gustavsson, U. (1972). A proposal for a classification of marine rockpools on the Swedish west coast. Botanica mar. 15: 210-214

Hawkins, S. J., Hartnoll, R. G. (1983). Grazing of intertidal algae by marine invertebrates. Oceanogr. mar. Biol. A. Rev. 21: 195-282

Hicks, G. R. F, Coull, B. C. (1983). The ecology of marine meiobenthic harpacticoid copepods. Oceanogr. mar. Biol. A. Rev. 21:67-175

Huggett, J., Griffiths, C. L. (1986). Some relationships between elevation, physico-chemical variables and biota of intertidal rock pools. Mar. Ecol. Prog. Ser. 29: 189-197

Janke, K. (1990). Biological interactions and their role in community structure in the rocky intertidal of Helgoland

This article was submitted to the editor
(German Bight, North Sea). Helgoländer Meeresunters. 44: $219-263$

Johnson, S. C., Scheibling, R. E. (1987). Reproductive patterns of harpacticoid copepods on intertidal macroalgae (Ascophyllum nodosum and Fucus vesiculosus) in Nova Scotia, Canada. Can. J. Zool. 65: 129-141

Kooistra, W. H. C. F., Joosten, A. M. T., van den Hoek, C. (1989). Zonation patterns in intertidal pools and their possible causes: a multivariate approach. Botanica mar. 32: $9-26$

Lawrence, J. M., McClintock, J. B. (1987). Intertidal invertebrate and algal communities on the rocky shores of the Bay of Morhiban, Kerguelen (southern Indian Ocean). P.S.Z.N. I: Mar. Ecol. 8: 207-220

Metaxas, A., Scheibling, R. E. (1993). Community structure and organization of tidepools. Mar. Ecol. Prog. Ser. 98: $187-198$

Naylor, E., Slinn, D. J. (1958). Observations on the ecology of some brackish water organisms in pools at Scarlett Point, Isle of Man. J. Anim. Ecol. 27: 15-25

Preston, A., Moore, P. G. (1988). The flora and fauna associated with Cladophora albida (Huds.) Kutz. from rockpools on Great Cumbrae Island, Scotland. Ophelia 29: 169-186

Sibert, J. R. (1981). Intertidal hyperbenthic populations in the Nanaimo estuary. Mar. Biol. 64: 259-265

Smith, R. I. (1964). Keys to marine invertebrates of the Woods Hole region. Contribution No. 11, Systematics-Ecology Program, Marine Biological Laboratory, Woods Hole, MA. Spaulding Co., Randolph, MA

Wilkinson, L. (1989). SYSTAT: the system for statistics. SYSTAT, Inc., Evanston, IL

Wolfe, J. M., Harlin, M. M. (1988). Tidepools in southern Rhode Island, U.S.A. II. Species diversity and similarity analysis of macroalgal communities. Botanica mar. 31: 537-546

Manuscript first received: July 5, 1993

Revised version accepted: February 10, 1994 